\title{
Milyen hatása van a COVID-19-járványnak a gyermekkori akut appendicitisekre?
}

\author{
Fadgyas Balázs dr. - Garai Gábor István dr. - Ringwald Zoltán dr. \\ Heim Pál Országos Gyermekgyógyászati Intézet, Sebészeti és Traumatológiai Osztály, Budapest
}

\begin{abstract}
Bevezetés: A COVID-19-pandémia miatt a gyermekkori appendicitisek kezelésében számos változás történt (laparoszkópia helyett nyílt műtét, antibiotikumkezelés). Világszerte emelkedett a szövődményes appendicitisek aránya. Célkitüzés: Munkánk során a COVID-19-járványnak a gyermekkori akut appendicitisekre kifejtett hatását szerettük volna vizsgálni: lett-e több perforált eset?

Módszerek: A 2012 és 2020 között akut vakbélgyulladás miatt operált gyermekeket vizsgáltuk, külön, havi bontásban a 2020-as eseteket. A szövettani diagnózis alapján perforált és nem perforált appendicitis csoportokat alkottunk. A 2020-ban operált betegek COVID-19-statusát is rögzítettük. Statisztikai analízisre a khi²-próbát ('chi ${ }^{2}$ test for trend') és a Fisher-féle egzakt tesztet alkalmaztuk.

Eredmények: A vizsgált időszakban 1343 appendectomia történt, többségében nem perforált akut appendicitis miatt (1166/1343). 2015-től kezdődően a perforált esetek aránya szignifikáns emelkedést mutat $(\mathrm{p}=0,0002)$. Az igazoltan COVID-19-pozitív betegek között magasabb volt a perforáltak aránya (5/8), mint az igazoltan negatív betegek között $(15 / 92)(\mathrm{p}=0,0075)$.

Megbeszélés: A nemzetközi trendeknek megfelelően 2020-ban osztályunkon is magasabb volt a perforált appendicitisek aránya, mint a korábbi években. Ez az emelkedés 2015-tól tart, a pandémiával nem mutat szoros összefüggést. A perforált appendicitisek COVID-19-pozitív betegek között észlelt magas arányának okát nem ismerjük.

Következtetés: További vizsgálat indokolt annak feltárására, hogy mi okozza a perforált appendicitisek COVID-19pozitív betegek között észlelt magas, illetve 2015 óta emelkedő rátáját.
\end{abstract}

Orv Hetil. 2021; 162(16): 608-610.

Kulcsszavak: COVID-19, appendicitis, gyermek

\section{How COVID-19 pandemic influences paediatric acute appendicitis cases?}

Introduction: As a result of the COVID-19 pandemic, the management of paediatric appendicitis has changed (open instead of laparoscopic appendectomy, antibiotic treatment). The number of complicated appendicitis cases increased worldwide.

Objective: Our aim was to study the effect of the COVID-19 pandemic on paediatric acute appendicitis: has there been more perforated cases?

Methods: Children operated because of acute appendicitis between 2012 and 2020 were studied. Cases from the year 2020 were analysed monthly. Patients were divided into perforated and non-perforated appendicitis groups according to their histological findings. COVID-19 status of patients in 2020 was studied. Chi ${ }^{2}$ test for trend and Fisher's exact test were used for statistical analysis.

Results: In the study period, 1343 appendectomies were performed. The majority of our cases were non-perforated (1166/1343). The rate of perforated appendicitis cases has been increasing from $2015(\mathrm{p}=0.0002)$. The number of perforated cases was higher in COVID-19 positive patients $(5 / 8)$ then in negative ones $(15 / 92)(\mathrm{p}=0.0075)$.

Discussion: In line with the international trend, more perforated appendicitis cases were treated in our departement in 2020. However, this increase started in 2015, and there is no correlation with the COVID-19 pandemic. The cause of the increased number of perforated cases in COVID-19 positive appendicitis patients is unknown.

Conclusion: The causes of the high proportion of perforated cases in COVID-19 positive patients and the rising rate of perforated appendicitis cases since 2015 need further studies.

Keywords: COVID-19, appendicitis, paediatric

Fadgyas B, Garai GI, Ringwald Z. [How COVID-19 pandemic influences paediatric acute appendicitis cases?] Orv Hetil. 2021; 162(16): 608-610.

(Beérkezett: 2021. január 27.; elfogadva: 2021. február 23.) 


\section{Rövidítések}

COVID-19 = (coronavirus disease 2019) koronavírus-betegség 2019; PCR = (polymerase chain reaction) polimeráz-láncreakció

A COVID-19-világjárvány minden ország egészségügyi rendszerét megterhelte, megterheli. A manuális osztályok múködése is nehezítetté vált, a legtöbb országban a tervezett mû́tétek leálltak, csak sürgősségi ellátás zajlik [1]. A leggyakoribb gyermekkori sebészeti sürgősségi kórkép a heveny féregnyúlvány-gyulladás. Európában a COVID-pandémia első hulláma többek között ÉszakOlaszországot érintette súlyosan, ahol a gyermekkori akut appendicitisek többsége komplikált formában jelentkezett [2]. Hasonló trend volt megfigyelhető ÉszakAmerikában [3]. A legtöbb gyermeksebészeti osztály új eljárásrendet alakított ki az appendicitisek kezelésére: előtérbe került a konzervatív antibiotikumkezelés [4], a mára alapvetővé vált laparoszkópos appendectomia helyett ismét nyílt mútéteket végeztünk [5].

Vizsgálatunk célja, hogy felmérje, hogyan hatott a COVID-járvány az osztályunkon kezelt appendicitises gyermekek ellátására: nőtt-e a perforált appendicitisek aránya?

\section{Módszerek}

Az intézetünk Sebészeti és Traumatológiai Osztályán 2012. január l. és 2020. december 31. között heveny féregnyúlvány-gyulladás gyanúja miatt akut appendectomián átesett gyermekeket vizsgáltuk. A 2020-ban operált betegek esetében havi bontást is végeztünk. Kizárási kritérium volt a tervezett appendectomia, hematoonkológiai betegség, egyéb, egy ülésben ellátást igénylő sebé-

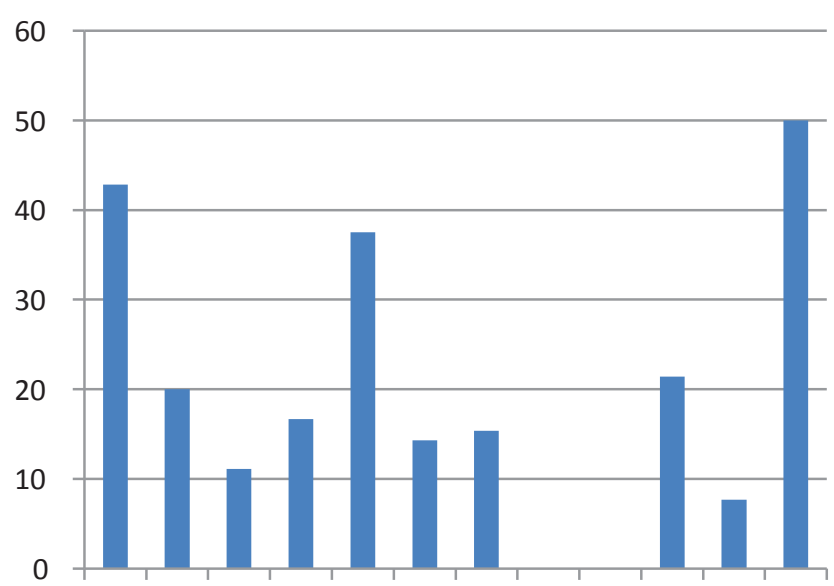

$\begin{array}{lllllllllll}1 . & 2 . & 3 . & 4 . & 5 . & 6 . & 7 . & 8 . & 9 . & 10 . & 11 .\end{array}$

A perforált appendicitisek aránya (\%)

1. ábra $\mid$ A perforált appendicitisek aránya 2020-ban havi bontásban $(1-12$.
1. táblázat Az appendicitisek, a nem perforált és a perforált esetek száma, a perforált esetek aránya éves bontásban

\begin{tabular}{lcccc}
\hline Év & $\begin{array}{c}\text { Összes } \\
\text { appendicitis }\end{array}$ & $\begin{array}{c}\text { Nem } \\
\text { perforált } \\
\text { appendicitis }\end{array}$ & $\begin{array}{c}\text { Perforált } \\
\text { appendicitis }\end{array}$ & $\begin{array}{c}\text { A perforált } \\
\text { appendicitisek } \\
\text { aránya }\end{array}$ \\
\hline 2012 & 137 & 128 & 9 & $6,57 \%$ \\
2013 & 127 & 107 & 20 & $15,75 \%$ \\
2014 & 165 & 146 & 19 & $11,52 \%$ \\
2015 & 145 & 136 & 9 & $6,20 \%$ \\
2016 & 169 & 149 & 20 & $11,83 \%$ \\
2017 & 145 & 125 & 20 & $13,79 \%$ \\
2018 & 139 & 118 & 21 & $15,11 \%$ \\
2019 & 168 & 139 & 29 & $17,26 \%$ \\
2020 & 148 & 118 & 30 & $20,27 \%$ \\
\hline Összesen & 1343 & 1166 & 177 & $13,15 \%$ \\
\hline
\end{tabular}

szeti kórkép jelenléte (például Meckel-diverticulum). A betegeket a szövettani diagnózis alapján osztottuk perforált és nem perforált csoportra. A 2020-ban appendectomián átesett betegek COVID-statusát is rögzítettük. Statisztikai analízisre a $\mathrm{khi}^{2}$-próbát ('chi ${ }^{2}$ test for trend') és a Fisher-féle egzakt tesztet alkalmaztuk.

\section{Eredmények}

A vizsgált időszakban 1343 appendectomia történt heveny féregnyúlvány-gyulladás gyanúja miatt osztályunkon. A betegek többsége nem perforált appendicitis miatt lett ellátva (1166/1343). 2015-tól kezdődően a perforált esetek aránya szignifikáns emelkedést mutat $(\mathrm{p}=0,0002)$ (1. táblázat).

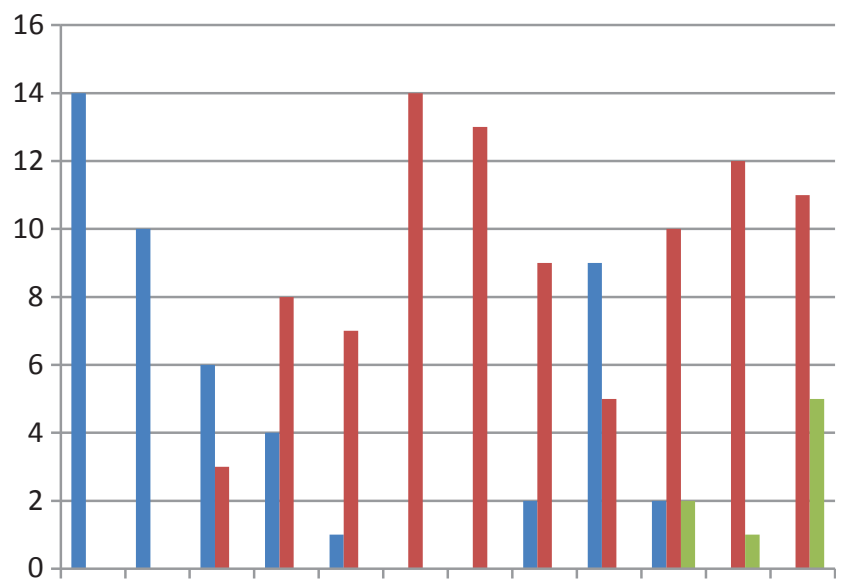

1. 2. 3. $4 . \quad 5.6 . \quad 7 . \quad 8.9 . \quad 10.11 .12$.

Ismeretlen COVID GOVID-negatív COVID-pozitiv

2. ábra $\quad$ Az akut appendicitis miatt operált betegek COVID-statusa, havi bontásban (1-12.)

COVID = koronavírus-betegség 2019 
A 2020-as évet havi bontásban vizsgálva januárban, májusban és decemberben észleltük a perforált esetek magas arányát az összes appendicitises esethez viszonyítva (1. ábra).

$\mathrm{Az}$ akut appendicitis miatt operált betegek körében alacsony volt a COVID-19-PCR-pozitivitás (az első teszt márciusban vált lehetővé, rutinszerüen májustól történt a betegek szúrése mütét előtt). Az első COVID-19PCR-pozitív appendicitises beteget októberben észleltük, a legtöbbet decemberben (2. ábra). Az ismeretlen COVID-19-statusú betegeknél PCR-teszt nem történt.

A 2020-as évet tekintve októberben és decemberben a perforált appendicitis miatt operált betegek között magas volt a COVID-19-pozitivitás (33,3\%, illetve 50\%). Az igazoltan COVID-19-pozitív betegek között magasabb volt a perforáltak aránya $(5 / 8,62,5 \%)$, mint a negatív betegek között $(15 / 92,16,3 \%)(\mathrm{p}=0,0075)$.

\section{Megbeszélés}

A COVID-19-járvány hazánkat inkább az őszi időszaktól kezdve érintette komolyabban. Már a tavaszi lezárások és járványügyi intézkedések is befolyásolták az addig megszokott ellátást, betegutakat. A sebészszakmák felfüggesztették az elektív mütéteket. A gyermeksebészek leggyakoribb akut mütéti tevékenységét jelentő appendectomiák eleinte nyílt mütét útján történtek, az egyébként arany standard laparoszkópia helyett [5]. Hazánkban a nemzetközi tapasztalatok alapján eleinte szintén nyílt appendectomiákat végeztünk, és amint biztonságos volt, visszatértünk a laparoszkópos ejáráshoz. Történtek próbálkozások nem komplikált esetekben az antibiotikumkezeléssel is [4]. Míg egyes országokban csökkent a gyermekkori akut appendicitises esetek száma [6, 7], addig osztályunkon nem észleltünk változást az elmúlt évekhez képest (1. táblázat). A nemzetközi trendeknek megfelelően $[2,3,8]$ osztályunkon is emelkedő tendenciát mutatott a szövődményes, perforált appendicitisek aránya. Ez az évről évre jelentkező emelkedő tendencia viszont 2015-től észlelhető, aminek okát jelenleg nem ismerjük, vélhetően nincs összefüggésben a jelenleg zajló világjárvánnyal. A havi bontást vizsgálva a perforált esetek és a járvány aktuális hazai állapota között összefüggést nem fedeztünk fel (mind januárban, mind decemberben igen magas volt a perforált appendicitisek száma).

\section{Következtetés}

A perforált appendicitis COVID-19-pozitív betegek között észlelt magas arányának okát jelenleg nem ismerjük, az alacsony esetszám is korlátozza a következtetések levonásának lehetőségét. Az új koronavírusnak lehet hatása az appendicitis lefolyására? Vagy a COVID-19-pozitív betegek ellátása nehézségekbe ütközött, a betegutak meghosszabbodtak, maguk a betegek nem mertek enyhébb panasszal kórházba menni? A járvány elmúltával a 2021. évi esetek feldolgozása is szükséges lesz az összefüggések mélyebb megismeréséhez. Indokolt továbbá annak vizsgálata is, hogy mi okozza a perforált esetek 2015 óta emelkedő számát.

Anyagi támogatás: A közlemény megírása és a kapcsolódó kutatómunka anyagi támogatásban nem részesült.

Szerzôi munkamegosztás: F. B. dolgozta fel az eseteket, átnézte a szakirodalmat és írta a dolgozatot. G. G. I. és R. Z. szakmailag véleményezte a munkát. A cikk végleges változatát valamennyi szerző elolvasta és jóváhagyta.

Érdekeltségek: A szerzőknek nincsenek érdekeltségeik.

\section{Köszönetnyilvánítás}

A szerzők köszönik $d r$. Sinkovits Györgynek a statisztikai analízisben nyújtott segítségét.

\section{Irodalom}

[1] Leva E, Morandi A, Sartori A, et al. Correspondence from Northern Italy about our experience with COVID-19. J Pediatr Surg. 2020; 55: 985-986.

[2] La Pergola E, Sgrò A, Rebosio F, et al. Appendicitis in children in a large Italian COVID-19 pandemic area. Front Pediatr. 2020; 8: 600320 .

[3] Orthopoulos G, Santone E, Izzo F, et al. Increasing incidence of complicated appendicitis during COVID-19 pandemic. Am J Surg. 2020 Sep 26. Available from: https://doi.org/10.1016/j. amjsurg.2020.09.026 [accessed: 23 February 2021].

[4] Bethell GS, Rees CM, Sutcliffe JR, et al. Management and early outcomes of children with appendicitis in the UK and Ireland during the COVID-19 pandemic: a survey of surgeons and observational study. BMJ Paediatrics Open 2020; 4: e000831.

[5] English W, Habib Bedwani N, Smith C, et al. Suspected appendicitis and COVID-19, a change in investigation and management. A multicentre cohort study. Langenbecks Arch Surg. 2020 Nov 9. Doi: 10.1007/s00423-020-02023-6. [Online ahead of print]

[6] Zvizdic Z, Vranic S. Decreased number of acute appendicitis cases in pediatric population during the COVID-19 pandemic: any link? J Pediatr Surg. 2021; 56: 199-200.

[7] Tankel J, Keinan A, Blich O, et al. The decreasing incidence of acute appendicitis during COVID-19: a retrospective multicentre study. World J Surg. 2020; 44: 2458-2463.

[8] Snapiri O, Rosenberg Danziger C, Krause I, et al. Delayed diagnosis of paediatric appendicitis during the COVID-19 pandemic. Acta Paediatr. 2020; 109: 1672-1676.

(Fadgyas Balázs dr., Budapest, Üllői út 86., 1089 e-mail: drfadgyasbalazs@gmail.com)

A cikk a Creative Commons Attribution 4.0 International License (https://creativecommons.org/licenses/by-nc/4.0/) feltételei szerint publikált Open Access közlemény, melynek szellemében a cikk bármilyen médiumban szabadon felhasználható, megosztható és újraközölhető, feltéve, hogy az eredeti szerző és a közlés helye, illetve a CC License linkje és az esetlegesen végrehajtott módositások feltüntetésre kerülnek. 